\title{
PENCEMARAN LAUT OLEH MINYAK
}

Oleh: Dra. Henita Rahmayanti, M.Si ${ }^{*}$

\begin{abstract}
Abstrak
Pencemaran laut adalah masuknya atau dimasukkannya mahluk hidup, zat, energi dan atau komponen lain ke dalam laut hingga merubah tatanan atau komposisi air karena kegiatan manusia atau karena proses alam, dan kualitas turun sampai ketingkat tertentu dan menyebabkan fungsi dari laut tidak sesuai dengan peruntukannya,Pencemaran laut terjadi karena banyak hal, antara lain sampah, bahan kimia dan yang paling menonjol permasalah pencemaran dilaut adalah minyak, baik yang berasal dari pemboran minyak, juga tumpahan minyak dari kegiatan transportasi di laut.Untuk mengurangi dampak negatif dari pencemaran laut oleh minyak, maka dikemukakan alternatif solusi antara lain penegakan peraturan dari undang-undang yang sudah ada dan pemakaian alat guna mengurangi atau mencegah pencemaran oleh minyak pada setiap kegiatan kapal.Perlidungan lingkungan perairan sangat penting, karena mengingat fungsi laut yang amat penting bagi kelangsungan hidup di muka bumi.
\end{abstract}

Kata kunci : pencemaran laut

\section{Pendahuluan}

Dilihat dari angkasa, sekitar $78 \%$ permukaan bumi kita adalah lautan. Laut merupakan cadangan terbesar untuk bahan-bahan mineral, energi, dan bahan makanan serta masih banyak bahan mineral lainnya yang terdapat di dalamnya. Selain itu laut juga merupakan sumber kehidupan bagi ekosistem binatang dan tumbuhan laut. Di bawah gelombang laut terdapat sejumlah besar ragam kehidupan, dari tanaman-tanaman laut sampai plankton (tumbuhan dan hewan kecil) hingga pada ikan paus yang sangat besar.

Selama ribuan tahun laut bermanfaat bagi manusia sebagai sumber daya alam (SDA). Seiring dengan perkembangan ilmu pengetahuan dan teknologi, pemberdayaan hasil laut yang dilakukan oleh manusia tidak diimbangi dengan perawatan dan pelestarian yang maksimal. Populasi dunia yang meningkat tidak saja menghasilkan sejumlah besar kotoran, tetapi juga zat-zat yang dihasilkan

oleh manusia dan alam lainnya menyebabkan tekanan yang serius pada 
kapasitas laut untuk mengedarkan limbah.

Banyak diantara kita tidak pernah melihat pengaruh dari pencemaran laut. Namun zat-zat seperti minyak, plastik, kotoran, zat-zat kimia untuk keperluan industri, pestisida, dan bahkan keradioaktifan, semuanya membahayakan kehidupan di dalam lautan. Jika kita meneruskan untuk menggunakan lautan sebagai tempat pembuangan yang tak terbatas, kita akan menanggung resiko pencemaran terhadap salah satu dari sumber daya bumi yang paling berharga. Laut sebagai SDA bagi manusia serta sumber kehidupan bagi ekosistem binatang dan tumbuhan, tercemar akibat ulah manusia yang membuang minyak dari kapal ke laut dan pengeboran minyak di laut lepas.

\section{Pembahasan}

Sumber dan akibat Pencemaran Laut.

Laut adalah kumpulan air asin yang banyak atau luas yang di dalamnya terdapat berbagai kehidupan laut seperti ikan, anjing laut, plankton, dan tumbuhan laut. Laut penting bagi seluruh kehidupan di atas daratan, karena laut mengandung lebih dari $90 \%$ air yang dikandung bumi, dan laut penuh akan sumber daya seperti protein, sumber daya alam, sebagai pengatur suhu atau thermostat yang menyerap panas matahari, serta merupakan sarana perhubungan.

Pencemaran laut adalah masuknya atau dimasukannya makhluk hidup, zat, energi, dan atau komponen lain ke dalam laut hingga merubah tatanan (komposisi) air karena kegiatan manusia atau karena proses alam, dan kualitas air turun sampai ketingkat tertentu dan menyebabkan fungsi dari laut tidak sesuai dengan peruntukannya.

Sumber pencemaran laut tersebut terdiri dari :

a. Air sungai yang membawa kotoran dari daratan.

b. Air buangan dari kota-kota dan daerah industri lewat saluran-saluran pembuangan yang bermuara ke laut.

c. Buangan limbah berasal dari tempat penggalian bahan-bahan mentah di dasar laut (pengeboran minyak).

d. Kotoran-kotaran yang terbawa oleh udara.

e. Zat-zat kimia yang dipakai untuk persawahan seperti pestisida yang terbawa oleh air sungai.

Sumber-sumber pencemaran laut tersebut dapat mengakibatkan : 
a. Bau yang menyengat yang timbul pada pantai laut, sungai, dan danau.

b. Rusak dan berkurangnya kehidupan hewan dan tumbuhan laut.

c. Mengapungnya minyak pada permukaan air laut.

d. Warna air yang tidak nomal/perubahan warna air.

\section{Pencemaran laut oleh Minyak}

Semula orang tidak banyak mengenal dasar laut karena belum banyak kepentingan di tempat yang menakutkan itu. Dasar laut sukar dicapai, lebih-lebih yang dalam. Teknologi untuk mencapai dan memanfaatkan dasar laut belum berkembang karena kebutuhan manusia masih dapat dicukupi sepenuhnya dari hasil alam di daratan yang lebih mudah pengambilannya.

Dengan pertambahan penduduk dan perkembangan peradaban kebutuhan yang makin kompleks, daratan tidak lagi mampu memberi kecukupan. Maka mulailah dasar laut dieksplorasi dan dieksploitasi.

Dasar laut yang masih merupakan kelanjutan dari benua, mengandung kekayaan serupa yang terdapat di daratan. Batu-batuan, pasir, kapur, minyak bumi, batu bara, dan mineral-mineral lain yang dapat ditambang di dasar laut dengan menggunakan teknologi yang lebih diperkembangkan. Indonesia juga sudah mulai mengeksploitasi dasar lautnya, seperti pengeboran minyak bumi lepas pantai di sebelah utara pulau Jawa untuk konsumsi kota-kota besar yang sudah menghabiskan material di daratan sekitarnya.

Secara sepintas eksploitasi dasar laut tidak merusak lingkungan karena dilakukan di bawah air. Namun resiko terjadinya kebocoran minyak bumi akibat pengeboran lepas pantai menyebabkan minyak menggenang dan mengapung di atas air laut yang akan mempengaruhi proses penyeimbangan oksigen dan karbondioksida (dalam air), dan menutup permukaan yang sangat berpengaruh pada kehidupan laut.

Sebuah perkiraan menyebutkan bahwa sekitar tiga juta ton minyak (seper-sepuluh dari produk minyak tahunan dunia) berakhir di laut setiap tahunnya. Polusi minyak tersebut sebagian besar berasal dari tangker-tangker rongsokan, pembersihan tangker minyak dan sisa produksi minyak yang dibuang ke laut, kecelakaan kapal pada saat beroperasi, serta limbah minyak pabrik dan mobil yang dibuang ke sungai bemuara ke laut.

Contoh kasus pencemaran laut oleh minyak adalah pada tanggal 24 Maret 1989, kapal tangker minyak EXXON Veldez karam di Prince William Sound Pencemaran Laut Oleh Minyak (Henita Rahmayanti, Dosen Jurusan Teknik Sipil, FTUNJ) 
di Alaska. Kapal tersebut menumpahkan lebih dari 42 juta liter minyak mentah. Tumpahnya minyak tersebut berpengaruh pada perusakan lingkungan sekitar. Sejumlah besar ikan, burung laut, dan berang-berang laut mati. Di pantai-pantai tempat minyak berada, binatang-binatang tersebut mati teracuni pada saat meminum dan berenang di air yang tercampur minyak. Penyebab utama kematian binatang tersebut adalah karena mimyak dapat menyumbat saluran pada bulu-bulu, sehingga kemampuan binatang untuk bertahan melawan suhu dingin menurun dan mengakibatkan kematian.

Dalam contoh kasus tersebut akibat dari tumpahan minyak yang mencemari laut tidak hanya sebatas itu saja, seperti :

1. Adanya minyak menyebabkan berkurangnya penetrasi sinar ke dalam air. Intensitas sinar di dalam air sedalam dua meter dari permukaan air yang mengandung minyak adalah $90 \%$ lebih rendah dari intensitas sinar pada kedalaman yang sama di dalam air yang bening.

2. Konsentrasi oksigen terlarut menurun dengan adanya minyak karena lapisan film minyak menghambat pengambilan oksigen oleh air.

3. Adanya lapisan minyak pada permukaan air akan mengganggu kehidupan binatang di laut.

4. Dengan adanya tumpahan minyak penetrasi sinar dan oksigen menurun sehingga dapat mengganggu kehidupan tanaman-tanaman laut.

Beberapa komponen yang menyusun minyak juga diketahui bersifat beracun terhadap berbagai hewan maupun manusia, tergantung dari struktur dan berat molekulnya. Komponen-komponen hidro karbon jenuh yang mempunyai titik didih rendah diketahui dapat menyebabkan anesti dan narkosis pada berbagai hewan tingkat rendah dan jika terdapat pada tingkat konsentrasi tinggi dapat mengakibatkan kematian. Komponen-komponen hidro karbon aromatik yang memiliki titik didih rendah terdapat dalama jumlah besar di dalam minyak dan merupakan komponen yang paling berbahaya, misalnya benzen, toluen dan xilen. Oleh sebab itu binatang dan tumbuhan tidak mampu bertahan melawan zat racun yang terkandung pada minyak. Bukan hanya hewan dan tumbuhan saja yang kehidupannya terganggu, manusia pun turut mengalami berkurangnya persediaan sumber makanan dan protein bahkan menganggu kesehatan manusia yang tinggal di sekitar laut dan manusia yang memakan ikan yang sebenarnya sudah tercemar.

MENARA, JURNAL TEKNIK SIPIL VOL. I, NO. 1, JANUARI 2006:63-74 
Minyak dapat diuraikan oleh bakteri secara alami namun memerlukan waktu yang lama. Proses penguraian minyak dapat dilakukan dengan lebih cepat oleh manusia namun memerlukan biaya yang mahal.

\section{Penetapan Peraturan dan Pelaksanaan}

Akibat adanya pencemaran laut oleh minyak mengakibatkan banyak kerugian dan malapetaka. Menanggapi hal tersebut, diadakanlah Konvensi Internasional mengenai penanganan dan pencegahan pencemaran laut oleh minyak yang dihadiri, disepakati dan diwajibkan untuk diterapkan oleh seluruh negara.

Konvensi tersebut terdiri dari :

a. The International Conference on Pollution of the Sea by Oil yang diadakan pada tahun 1926 menghasilkan kebijakan mengenai :

- Setiap kapal yang memakai bahan bakar minyak atau mengangkut minyak diwajibkan untuk memasang alat pemisah air berminyak OWS (Oily Water Separator).

- Menetapkan zona-zona lautan dimana tidak diperkenankan membuang minyak.

b. Konfrensi Internasional tentang pencemaran oleh minyak di laut pada tahun 1954 yang menghasilkan berdirinya IMCO (Inter-Governmental Maritime Consultative Organization) di tahun 1959.

c. Konvensi MARPOL (Marine Pollution) pada tahun 1973 pada lampiran I (peraturan tentang pencegahan penccemaran oleh minyak) berisikan :

- Kapal-kapal tangki baru (New Tankers), pembuangan minyaknya dibatasi, maksimum pada Ballast Voyage sebanyak 1/30.000 dari jumlah muatan minyak.

- Kapal-kapal tangki minyak lama (Old Tangkers) memakai standar penbuangan 1/15.000 jumlah muatan minyak.

- Definisi minyak diperluas termasuk minyak-minyak tidak keras sebagaimana minyak hitam dan jenis-jenis yang telah dicakup sebelumnya.

- Konsep daerah-daerah khusus.

Konvensi tersebut dianggap suatu pemecahan permasalahan untuk mencegah dan menanggulangi masalah pencemaran oleh minyak di laut. 


\section{Penetapan Peraturan}

Sebagaimana telah dikemukakan di atas, ketentuan-ketentuan mengenai pencemaran lebih terinci dan mempunyai akibat yang lebih khusus. Pendekatan dasarnya adalah bahwa setiap negara diwajibkan untuk menetapkan ketentuanketentuan dan standar-standar internasional untuk mencegah, mengurangi dan mengendalikan pencemaran lingkungan laut oleh kapal-kapal, serta mendorong penetapan sistem pe-rute-an yang dirancang untuk mengurangi ancaman kecelakaan yang dapat menimbulkan pencemaran.

Mengenai yuridiksi khusus negara pantai atau negara pelabuhan ditetapkan bahwa :

a. Suatu negara, baik sendiri maupun bekerjasama dengan negara lain, menetapkan persyaratan-persyaratan khusus untuk pencegahan pencemaran, sebagai suatu syarat pemberian akses kesalah-satu pelabuhannya. Negara tersebut harus mengumumkan persyaratannya dan menyampaikannya kepada organisasi yang kompoten (International Maritime Organization).

b. Di laut teritorialnya, suatu negara pantai dapat menetapkan peraturan perundang-undangan untuk pencegahan, pengurangan dan pengendalian pencemaran laut dari kapal asing.

c. Kewenangan suatu negara pantai di zona ekonomi eksklusif lebih terbatas. Untuk tujuan pelaksanaan/penegakan, negara tersebut dapat menetapkan peraturan perundang-undangan sepanjang sesuai dan merupakan pelaksanaan ketentuan-ketentuan dan standar-standar internasional yang diterima secara umum (pasal 211 (5)).

d. Bagaimanapun jika ketentuan-ketentuan dan standar-standar internasional yang diterima secara umum tidak memadai untuk keadaankeadaan khusus, dan suatu negara pantai mempunyai alasan yang kuat untuk menganggap bahwa pada suatu daerah tertentu yanh jelas merupakan daerah di zona ekonomi eksklusifnya diperlukan penetapan tindakan-tindakan khusus untuk mencegah pencemaran dari kapal, maka setelah berkonsultasi dengan negara-negara lain, negara tersebut dapat menyampaikan bukti ilmiah kepada organisasi internasional yang kompeten untuk membuktikan perlunya tindakan-tindakan khusus tersebut. Dan setelah organisasi tersebut mengeluarkan keputusannya, 
negara pantai dapat mengambil tindakan-tindakan khusus pada daerah yang dipersoalkan.

\section{Penegakan/Pelaksanaan}

Dari ketentuan-ketentuan di bawah ini akan tampak betapa sulitnya untuk menghasilkan peraturan-peraturan yang dapat diterima baik oleh negara-negara pantai yang mengharapkan kewenangan yang besar untuk mengatur kapal asing, maupun oleh negara penjelajah lautan yang menentang.

Pasal 217 menyangkut pemaksaan pentaatan oleh suatu negara terhadap kapal-kapal yang menggunakan kebangsaannya, hal mana dahulu merupakan ssesuatu yang selaku tidak efektif.

Negara-negara harus menjamin bahwa kapal-kapal yang mengibarkan benderanya mentaati ketentuan-ketentuan dan standar-standar internasional yang berlaku dan peraturan perundang-undangan nasionalnya untuk mencegah, mengurangi dan mengendalikan pencemaran laut. Dan mereka harus menjamin bahwa kapal-kapal yang mengibarkan benderanya tidak berlayar ke laut kecuali apabila kapal-kapal tersebut mentaati persyaratan internasional (khususnya yang berhubungan dengan disain, konstruksi, perlengkapan dan pengawakan). Dan selanjutnya mereka harus menjamin bahwa kapal-kapal tersebut membawa sertifikat yang diwajibkan di atas kapal. Apabila sebuah kapal melanggar suatu ketentuan atau standar internasional, negara bendera (baik atas prakarsa sendiri ataupun permintaan negara lain) harus melakukan pemeriksaan segera, dan apabila diperlukan mengadakan penuntutan hukum, tanpa memandang dimana pelanggaran terjadi.

Negara pelabuhan juga mempunyai yuridiksi dalam hal-hal tertentu. Pasal 218 menyatakan bahwa apabila suatu kapal secara sukarela berada di suatu pelabuhan, negara pelabuhan dapat mengadakan pemeriksaan terhadap kemungkinan pembuangan yang melanggar hukum dari kapal itu di luar perairan pedalaman, laut teritorial atau zona ekonomi eksklusif negara yang bersangkutan. Pada prinsipnya negara pelabuhan juga berhak untuk mengadakan penuntutan dengan batasan tertentu, apabila pembuangan dilakukan di perairan pedalaman, laut teritorial atau zona ekonomi eksklusif negara lain. Selanjutnya negara pelabuhan dapat melarang suatu kapal untuk berlayar apabila kapal tersebut dianggap telah melanggar ketentuan-ketentuan 
dan standar-standar internasional yang berhubungan dengan kelaikan laut yang karenanya menimbulkan ancaman kerusakan pada lingkungan laut (pasal 219).

Pasal 220 tentang pemaksaan pentaatan oleh negara pantai terhadap kapal-kapal asing merupakan hasil di sini secara khusus tergambar persengketaan antara negara-negara pantai yang menuntut kewenangan yang luas di daerah ini dan negara-negara pengarung lautan yang menentangnya. Akibatnya, pasal 220 tidaklah sederhana. Hal-hal yang paling penting dari ketentuan ini adalah :

a. Apabila suatu kapal secara sukarela berada dalam suatu pelabuhan, negara pelabuhan dapat mengadakan penuntutan yang bertalian dengan setiap palanggaran peraturan perundang-undangannya, yang ditetapkan sesuai dengan ketentuan-ketentuan dan standar-standar internasional yang berlaku, apabila pelanggaran itu terjadi di laut teritorial atau zona ekonomi eksklusif negara itu (pasal 220 (1));

b. Apabila ada alasan yang jelas untuk menduga suatu kapal yang berlayar di laut teritorial suatu negara pantai, selama lintasannya telah melakukan pelanggaran terhadap peraturan perundang-undangan negara itu yang telah ditetapkan sesuai dengan ketentuan dan standar internasional yang berlaku, negara pantai dapat melakukan pemeriksaan kapal secara fisik, dan apabila terdapat pembuktian yang cukup dapat dilakukan penuntutan (pasal $220(2)$ );

c. Apabila ada alasan yang jelas untuk menduga bahwa suatu kapal yang berlayar di zona ekonomi eksklusif atau laut teritorial suatu negara telah melanggar ketentuan dan standar internasional (atau peraturan perundang-undangan negara tersebut sebagai penerapan darinya), negara itu dapat mewajibkan kapal untuk memberikan informasi mengenai identitasnya (pasal 220 (3)

d. Apabila dalam keadaan-keadaan yang digambarkan di atas, pelanggaran menimbulkan pelepasan substansial yang mengakibatkan atau mengancam akan menimbulkan pencemaran yang berat terhadap lingkungan laut, negara pantai dapat melakukan pemeriksaan secara fisik. Apabila kapal tersebut menolak untuk memberikan informasi yang diminta atau memberikan informasi yang jelas tidak benar (pasal 220 (5));

e. Apabila dalam keadaan-keadaan yang digambarkan di atas,pelanggaran menimbulkan suatu pelapasan yang mengakibatkan atau mengancam 
akan menimbulkan kerusakan berat di daerah pantai atau sumber kekayaan alam di laut teritorial atau zona ekonomi esklusifnya, maka pada prinsipnya dapat juga mengadakan penuntutan terhadap kapal, termasuk penahanannya (pasal $220(6)$ ).

\section{Pengamanan}

Ketentuan-ketentuan di atas tidak memberikan suatu gambaran yang lengkap mengenai pengaturan yang diciptakan Konvensi untuk menangani pencemaran laut oleh kapal. Suatu komponen inti dari kompromi yang dicapai terdiri dari langkah-langkah pengamanan tertentu bagi perlindungan kapal-kapal asing. Langkah-langkah pengamanan yang paling penting diantaranya adalah :

a. kewenangan-kewenangan pemaksaan pentaatan terhadap kapal-kapal asing hanya dapat dilaksanakan oleh para pejabat, kapal-kapal perang, pesawat udara militer atau kapal/pesawat udara lain yang diberi tanda jelas dan dapat dikenal sebagai sedang dalam dinas pemerintah serta diberi kewenangan untuk melakukan tindakan (pasal 224).

b. Pemaksaan pentaatan tidak boleh dilaksanakan dengan suatu cara yang dapat menimbulkan bahaya terhadap pelayaran suatu kapal atau lingkungan laut (pasal 225).

c. Kapal-kapal asing tidak boleh ditahan lebih lama dari yang diperlukan untuk tujuan pemeriksaan. Pemeriksaan harus dibatasi, pertama pada pemeriksaan surat-surat yang disyaratkan bagi kapal dan kapal itu hanya dapat diperiksa sesuai dengan syarat-syarat tertentu. Bahkan bila ditemukan suatu pelanggaran, kapal harus segera dibebaskan walaupun dengan kewajiban untuk memberikan uang jaminan, atau umtuk keperluan berlayar ke galangan perbaikan terdekat (pasal 226).

d. Negara-negara tidak boleh melakukan diskriminasi terhadap kapal-kapal asing dan kapal-kapal milik mereka sendiri (pasal 227).

e. Apabila suatu negara telah mengadakan penuntutan pidana terhadap suatu kapal asing yang melakukan pelanggaran di luar laut teritorial, penentuan serupa oleh negara bendera dalam jangka waktu enam bulan setelah penuntutan pertama, kecuali kalau penuntutan tersebut berhubungan dengan suatu pelanggaran yang telah mengakibatkan kerusakan berat kepada negara pantai, atau apabila negara bendera berulangkali telah mengabaikan kewajiban-kewajibannya untuk 
melakukan pemaksaan pentaatan terhadap kapal-kapalnya sendiri. Penuntutan yang ditangguhkan di negara pantai dianggap berakhir pada saat penuntutan di negara bendera telah berakhir pula (pasal 228 (1)).

f. Denda uang hanya dapat dikenakan terhadap pelanggaran-pelanggaran yang dilakukan oleh kapal-kapal asing di luar laut teritoial. Hal yang sama berlaku bagi pelanggaran-pelanggaran oleh kapal-kapal asing di luar laut teritorial. Hal yang sama berlaku bagi pelanggaran-pelanggaran kapalkapal asing di laut teritorial, kecuali dalam perkara perbuatan pencemaran yang disengaja dan gawat (pasal 230).

g. Negara-negara bendera harus segera diberitahukan tentang tindakantindakan pemaksaan pentaatan yang dilakukan oleh negara lain (pasal 231), dan apabila penegakan dilaksanakan secara tidak sah, negara yang bersangkutan dapat dianggap bertanggung jawab (pasal 232).

\section{Peraturan di Indonesia}

Indonesia sebagai negara maritim tidak ketinggalan untuk turut menjaga lingkungan khususnya laut dengan menetapkan peraturan sebagai berikut :

a. Besarnya bobot ilmiah dari AMDAL dapat ditetapkan oleh pasal 28 ayat (2) Peraturan Pemerintah no.20 Tahun 1990 tentang pengendalian pencemaran air, yang berbunyi: "Bila analisis mengenai dampak lingkungan bagi suatu kegiatan mensyaratkan baku mutu limbah cair yang lebih ketat dari baku mutu limbah cair sebagaimana dimaksud dalam Pasal 15 maka untuk kegiatan tersebut ditetapkan baku mutu limbah cair sebagaimana disyaratkan oleh analisis mengenai dampak lingkungan".

b. Aspek hukum pidana dalam Undang-undang Lingkungan Hidup terdapat dalam Pasal 22, yang berbunyi: "Barang siapa dengan sengaja melakukan perbuatan karena kelalaiannya melakukan perbuatan yang menyebabkan rusaknya lingkungan hidup atau tercemarnya lingkungan hidup dapat dipidana.

c. Pasal 5 ayat (1) Undang-undang Lingkungan Hidup menyebutkan bahwa setiap orang mempunyai hak atas lingkungan hidup yang baik dan sehat. Pasal 5 ayat (2) Undang-undang Lingkungan Hidup menyebutkan bahwa memelihara lingkungan hidup dan mencegah serta menanggulangi pencemaran dan kerusakan lingkungan merupakan kewajiban hukum setiap orang.

MENARA, JURNAL TEKNIK SIPIL VOL. I, NO. 1, JANUARI 2006:63-74 
d. Diterapkannya Lindungan Lingkungan Perairan (LLP) demi terjaminnya penyelenggaraan layanan kegiatan angkutan laut BBM dan non-BBM di wilayah kerja Pertamina UPms III dengan lancar dan aman.

Sasaran kegiatan LLP ini adalah :

- Terselenggaranya kegiatan pencegahan, penanggulangan pencemaran dan tumpahan minyak di wilayah Dersus Migas Pertamina UPms III instalansi Tanjung Priuk baik skala kecil, sedang ataupun besar dengan baik, aman.

- Terselenggaranya penanggulangan tumpahan minyak dan pencemaran akibat pihak ketiga yang terjadi dalam wilayah perairan Dersus Migas Pertamina UPms III Instalansi Tanjung Priuk dalam rangka pelestarian lingkungan perairan.

- Tingkat pencemaran di wilayah Dersus Migas Pertamina UPms III yang relatif rendah dam senantiasa mengalami penurunan.

- Terselenggaranya kegiatan penanggulangan pencemaran dengan cepat dan tepat sasaran sehingga mengurangi potensi meluasnya daerah perairan tercemar.

\section{Kesimpulan}

1. Pencemaran oleh minyak disebabkan oleh :

a. Mulainya manusia mengeksplorasi dan mengeksploitasi persediaan sumber daya alam.

b. Bocornya pipa-pipa pertambangan minyak.

c. Kecelakaan kapal.

2. Akibat pencemaran oleh minyak di laut adalah :

a. Rusaknya ekosistem kehidupan di laut, bahkan kematian hewan, tumbuh-tumbuhan dan manusia.

b. Pengurangan kadar oksigen dan penetrasi cahaya matahari ke dalam lautan.

3. Keberadaan peraturan dan perundang-undangan sangat mempengaruhi pencemaran laut khususnya oleh minyak.

4. Lingkungan perairan di Indonesia juga mulai dilestarikan, ini dapat terlihat dengan ikutnya Indonesia menetapkan peraturan-peraturan dan melaksanakan LLP.

Pencemaran Laut Oleh Minyak (Henita Rahmayanti, Dosen Jurusan Teknik Sipil, FTUNJ) 


\section{Saran}

1. Tiap negara khususnya Indonesia lebih memperketat Peraturannya misalnya dengan memeriksa secara fisik dari kelengkapan sertifikat laik laut hingga peralatan yang dimiliki kapal tersebut guna mengurangi pencemaran laut.

2. Jika diketahui kapal tersebut mencemari laut, kapal dilarang masuk ke perairan dengan dikenakan denda atas kerugian atau jika pelanggaran dikarenakan kapal rusak pihak Indonesia memasukan kapal tersebut ke dalam galangan perbaikan dan tetap dikenakan denda atas kurugian.

3. Tiap negara khususnya Indonesia seharusnya melarang adanya pembuangan limbah industri dan pembuangan minyak oleh kapal dengan batas tidak kurang dari 50 mil dari daratan.

4. Peraturan yang telah ada diberlakukan, ditaati, dan dilaksanakan dengan baik.

\section{Daftar Pustaka}

Drs. Daryanto. Masalah Pencemaran. Bandung : Tarsito, 1995.

Fardiaz, Srikandi. Polusi Air dan Udara. Yogyakarta : Kanisius, 1992.

Hare, Tony. Selamatkan Bumi Kita: Pencemaran Laut. Semarang : PT. Mandiri Jaya Abadi.

Prawiro, H. Ruslan. Ekologi Lingkungan Pencemaran. Semarang : Satya Wacana, 1988.

Silalahi, Daud. AMDAL dalam Sistem Hukum Lingkungan di Indonesia. Bandung : CV. Mandar Maju, 1995.

Koers, W. Albert. Konvensi Perserikatan Bangsa-bangsa Tentang Hukum Laut. Yogyakarta : Press UGM, 1991.

Henita. Diktat Perkuliahan Marine Pollution. Jakarta : Universitas Negeri Jakarta, 2006. 